\title{
NOTE
}

\section{Heat shock proteins of the oyster parasite Perkinsus marinus}

\author{
C. T. Tirard ${ }^{1}$, R. M. Grossield ${ }^{1, *}$, A. K. Volety ${ }^{2}$, F.-L. E. Chu ${ }^{2}$ \\ ${ }^{1}$ Department of Zoology and Animal Physiology Program, College of Agriculture and Life Sciences, North Carolina State University, \\ Raleigh, North Carolina 27695-7617, USA \\ ${ }^{2}$ Virginia Institute of Marine Science, The College of William and Mary, Gloucester Point, Virginia 23062, USA
}

\begin{abstract}
The susceptibility of the eastern oyster Crassostrea virginica to infection by the protozoan parasite Perkinsus marinus is influenced by temperature. Because of the crucial roles of heat shock proteins in cellular thermal tolerance and in host-parasite adaptations in other species, we compared the in vitro heat shock responses of cultured $P$. marinus and of oyster hemocytes. The parasite and host heat shock proteins were different in size and in immunochemical specificity. In addition, the thermal threshold for inducing the response was higher for $P$. marinus acclimated to the same temperature as the oysters. The results suggest that $P$. marinus is likely to employ heat shock proteins as part of its adaptive survival repertoire and that it may be able to function normally under conditions of hyperthermia that evoke an emergency physiological response from the oyster defense cells. Furthermore, they indicate that it is feasible to investigate the host's and parasite's adaptive responses to each other, since their individual responses are readily distinguishable.
\end{abstract}

KEY WORDS: Parasite - Perkinsus maninus - Oysters · Crassostrea virginica - Hemocytes - Stress proteins - Hyperthermia

The progressive decrease in oyster Crassostrea virginica harvests along much of the eastern seaboard of the United States during the last 3 decades has been attributed primarily to mortality associated with 2 protozoan parasites, Perkinsus marinus and Haplosporidium nelsoni (Andrews 1988). The impact of these pathogens is determined to a large extent by ambient salinity and temperature (Haskin \& Ford 1982, Chu \& LaPeyre 1993, Chu et al. 1993, Ragone \& Burreson 1993). In laboratory and field studies on intact oysters, the prevalence and intensity of infection by $P$. marinus were shown to be greatest at a salinity of about 26 to $32 \mathrm{ppt}$ and a temperature of about 20 to $28^{\circ} \mathrm{C}$ and least at low salinity and temperature.

The effect of temperature and salinity could reflect a differential adaptability of the host and parasite. For

\footnotetext{
- Addressee for correspondence
}

example, in vitro studies with isolated oyster hemocytes have indicated an influence of these factors on the defense-related functions of spreading time, rate of movement, and foreign particle binding (Fisher 1988, Fisher \& Tamplin 1988, Fisher et al. 1992). On the other hand, the effect of temperature and salinity could reflect a differential sensitivity of the host and parasite. For example, in vitro studies with Haplosporidium nelsoni (Ford \& Haskin 1988) or Perkinsus marinus (Calvo et al. 1994) have indicated that these parasites may be more vulnerable than the oyster cells to an osmotic shock. In particular, after exposure to a salinity of about $4 \mathrm{ppt}$, the parasites are less viable than the hemocytes. This may account in large part for the low incidence of infection of oysters in low salinity environments.

These studies lead to the conclusion that the outcome of the pathogenic challenge will be determined by factors that affect the innate ability of the host and parasite to respond to their common environment. Since a period of Perkinsus marinus development is spent within the host's hemocytes or other cells (Andrews 1988), the outcome of the interaction also may be dependent on the response of this parasite and the hemocytes to each other.

Based upon studies of vertebrate cells and their natural parasites, the induced synthesis of stress proteins ('SPs') is a biochemical mechanism that is likely to be important for the responses of oyster defense cells and of Perkinsus marinus to both environmental and biological challenges. These highly conserved proteins are essential for housekeeping and adaptive functions in virtually all animal cells (Lindquist \& Craig 1988, Welch et al. 1989, Angelidis et al. 1991, Lathigra et al. 1991, Li et al. 1991, Nover 1991, Polla 1991, Solomon et al. 1991, Morimoto 1993, Young et al. 1993). Vertebrate immune cells and microorganisms, including protozoan parasites, exhibit similar SP responses 
to heat and other ambient shocks (Lathigra et al. 1991, Nover 1991, Polla 1991, Shinnick 1991, Murray \& Young 1992, DeNagel \& Pierce 1993). In parasites, induction of SPs, for example by exposure to the elevated temperature of a new host, is believed to be an important determinant of virulence towards the host (Lathigra et al. 1991). It is also considered to be an adaptation that allows the parasite to survive and differentiate within the confines of a potentially threatening host cell environment (Lathigra et al. 1991, Murray \& Young 1992). On the other hand, because SPs are the dominant antigens of a broad array of microbes, they trigger reactive responses of vertebrate immune cells that protect the host (Shinnick 1991. Healy et al. 1992, Murray \& Young 1992, Kantengwa \& Polle 1993, Young et al. 1993). In fact, it is tho capacity of macrophages and lymphocytes to recognize microbial SPs and to respond to them utilizing their own SP response that is believed to insure the outcome of the interaction in favor of a healthy host (Ciavarra \& Simeone 1990, Donati et al. 1991, Polla 1991. Healy et al. 1992, Murray \& Young 1992, Kantengwa \& Polla 1993, Young et al. 1993).

Using the vertebrate studies as a model, we have been investigating the response of oyster hemocytes to ambient stresses as a means of understanding how these cells adapt to potential threats to their survival. In a previous publication (Tirard et al. 1995), we reported that an acute heat shock of oyster hemocytes in vitro induced the synthesis and accumulation of the class of stress proteins known as heat shock proteins ('HSPs'), some of which may also be induced by a variety of other stresses (Lindquist \& Craig 1988, Welch et al. 1989, Nover 1991). In this communication, we report that a similar in vitro heat stress to Perkinsus marinus induced a comparable set of HSPs.

Materials and methods. Perkinsus marinus merozoites/meronts were cultured at $26^{\circ} \mathrm{C}$ in $25 \mathrm{~cm}^{2}$ flasks containing $10 \mathrm{ml}$ of modified DMEM:Ham's F-12 nutrient mixture (Gauthier \& Vasta 1993). The cultured cells varied between 3 and $20 \mu \mathrm{m}$ in size and consisted of about $95 \%$ merozoites/meronts and a few prezoosporangia stage cells ( $<5 \%$ of the total). The various life stages of the parasite, representing about 5 to $12 \times 10^{6}$ particles, were collected together by centrifugation of $1 \mathrm{ml}$ medium at $25 \times g$ for $10 \mathrm{~min}$. The supernatant was removed immediately from the loosely compacted pellet to minimize loss of cells. The parasites were resuspended in $1 \mathrm{ml}$ Medium 199 adjusted to 25 ppt salinity, for treatment at $25,37,42$, or $46^{\circ} \mathrm{C}$ for $1 \mathrm{~h}$. Then, they were pelleted and resuspended in another $1 \mathrm{ml}$ modified Medium 199 for a $2 \mathrm{~h}$ recovery at $25^{\circ} \mathrm{C}$, after which they were incubated at $25^{\circ} \mathrm{C}$ and 25 ppt salinity with $1 \mathrm{ml}$ Earles Balanced Salt Solution containing radioactive methionine and cystine. The procedures for cell incubation and lysis, quantitation of incorporated amino acid, and for detection of radioactive proteins by SDS (sodium dodecyl sulfate) polyacrylamide gel autoradiography were identical to those reported in another publication (Tirard et al. 1995). At least $95 \%$ of the cells were judged to be viable by their lack of staining with trypan blue at the start of the experiment and after the recovery period.

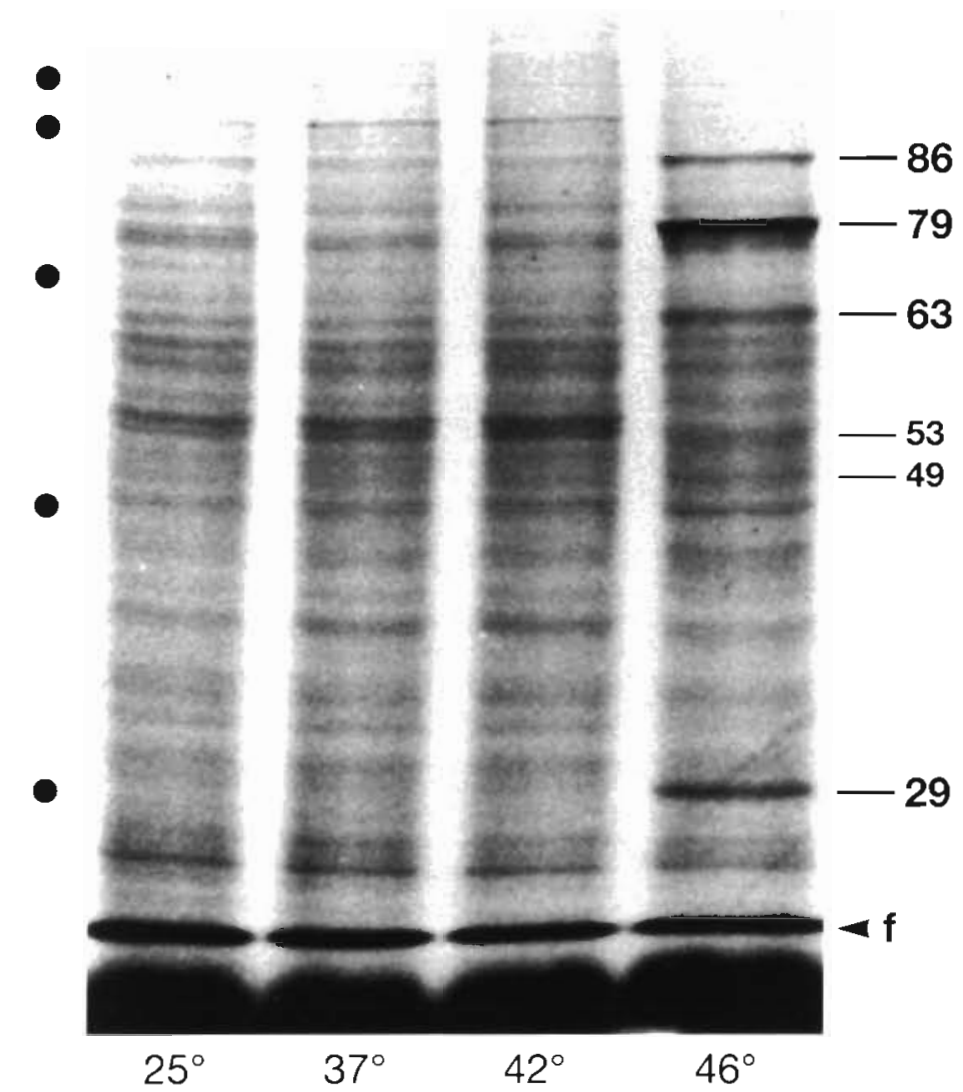

Fig. 1 Perkinsus marinus. Effect of temperature on parasite protein synthesis. Samples of cultured $P$. marinus were incubated in vitro at 25 , 37,42 , or $46^{\circ} \mathrm{C}$ for $1 \mathrm{~h}$. Afterwards, they were incubated for $2 \mathrm{~h}$ at $25^{\circ} \mathrm{C}$, and then for $1 \mathrm{~h}$ at $25^{\circ} \mathrm{C}$ with radioactive amino acid. Gel lanes were loaded with equal amounts of protein radioactivity. The major heatinduced radioactive proteins are denoted by solid lines at the right of the gel autoradiograph, next to calculated estimates of their molecular masses (in $\mathrm{kDa}$ ). Solid circles at the left indicate, from the top down, the corresponding locations of non-radioactive protein standards of 116 , $97.4,66,45$, and $29 \mathrm{kDa}$. The arrow and letter $\mathrm{f}$ near the bottom right of the gel in each figure indicate the location of the dye front 
Results and discussion. When the parasites were incubated at the control temperature of $25^{\circ} \mathrm{C}$, significant amounts of large and medium-size radioactive proteins were produced. Most of the radioactive amino acid was incorporated into small polypeptides that migrated at or just ahead of the dye front at the bottom of the gel (Fig. 1), where most of the Coomassie Blue-stained tissue protein was located. These results suggest either

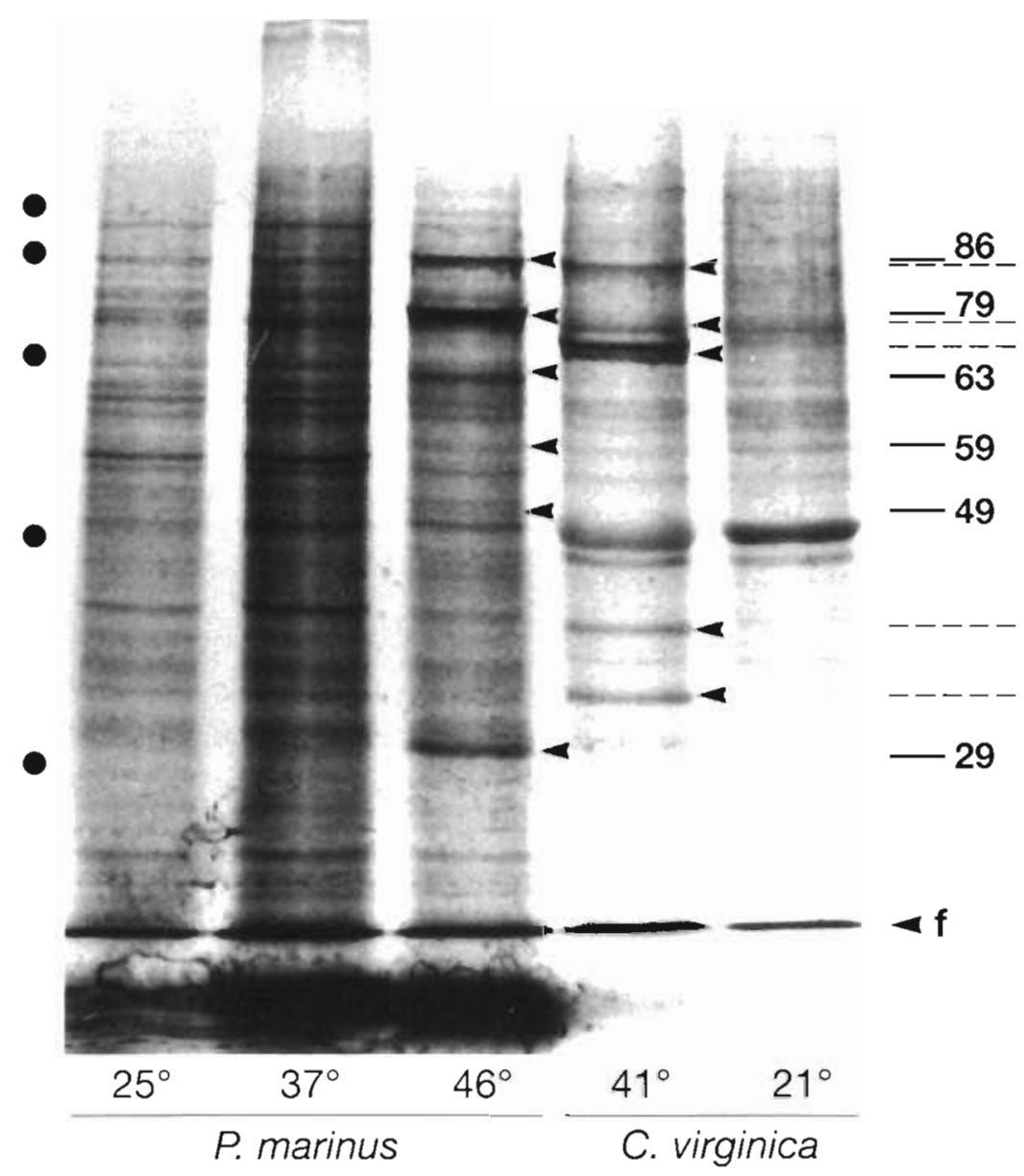

Fig. 2. Perkinsus marinus and Crassostrea virginica. Comparative heat shock responses of parasites and oyster hemocytes. Samples of cultured P. marinus or of $C$. virginica hemocytes were incubated separately in vitro for $1 \mathrm{~h}$ at the control temperature $\left(25\right.$ or $21^{\circ} \mathrm{C}$, respectively) or at an elevated temperature. Afterwards, they were incubated for $2 \mathrm{~h}$ at the control temperature, and then for $1 \mathrm{~h}$ at the control temperature with radioactive amino acid. Samples from the 2 species were arranged in opposite order on the gel to facilitate comparison of the respective heat shock responses. The major heat-induced radioactive proteins of the parasite at $46^{\circ} \mathrm{C}$ are denoted by thick solid lines and estimated molecular masses (in $\mathrm{kDa}$ ) at the right of the gel autoradiograph, with corresponding arrowheads to the right of the $46^{\circ} \mathrm{C}$ lane. The $37^{\circ} \mathrm{C}$ sample has the same protein profile as the $25^{\circ} \mathrm{C}$ sample but all of its bands are proportionally darker because more protein radioactivity was inadvertently applied to this lane. The major heat-induced radioactive proteins of the oyster cells at $41^{\circ} \mathrm{C}$ are denoted by thin broken lines at the right of the autoradiograph, with corresponding arrowheads to the right of the $41^{\circ} \mathrm{C}$ lane. Solid circles at the left indicate, from the top down, the corresponding locations of non-radioactive protein standards of $116,97.4$,

66,45 , and $29 \mathrm{kDa}$ that the cells normally produce an abundance of such olypeptides or that the incubation or culture condi no change in amino acid incorporation or in the pattern of protein synthesis. However, parasites incubated at $46^{\circ} \mathrm{C}$ for $1 \mathrm{~h}$ incorporated only one-third as much tracer into protein as the control samples and expressed a characteristic heat shock response involving synthesis of HSPs of various sizes. The most prominent parasite HSPs had molecular masses of about 86, 79, 63, and $29 \mathrm{kDa}$ (Fig. 1). Careful examination of the autoradiographs revealed that none of these bands corresponded in size to radioactive proteins present in the samples at lower temperatures. Thus, like the 'inducible' HSPs of other species, their synthesis was preferentially activated by an appropriate stress and likely to contribute significantly to cellular adaptation to such stress (Welch et al. 1989). These HSPs are similiar in size to those induced by a less severe heat stress of oyster hemocytes in vitro. The most prominent hemocyte HSPs had molecular masses of about 85, 70, 37, 34 , and $32 \mathrm{kDa}$ (Tirard et al. 1995).

The parasite and host heat shock responses were clearly distinguishable in 5 respects (Fig. 2). First, the HSPs were different in size. Second, the thermal threshold for inducing the response by $1 \mathrm{~h}$ in vitro was higher for Perkinsus marinus than for oyster hemocytes, requiring more than $42^{\circ} \mathrm{C}$ for the former but only 39 to $41^{\circ} \mathrm{C}$ for the latter in these and previous experiments. This was true whether the parasite had been held previously for $1 \mathrm{wk}$ or more at 25 or $21^{\circ} \mathrm{C}$. Third, in Western blots the parasite HSPs did not significantly bind a monoclonal antibody (clone 3a3; Affinity BioReagents, Neshantic, NJ, USA) that recognizes 2 HSP70 isoforms in oyster hemocytes (Tirard et al. 1995). Fourth, unless subjected to a very severe heat shock, the oyster hemocytes produced little if any radioactive polypeptide smaller than the bromophenol blue tracking dye at $2 \mathrm{~h}$ whereas most of the label incorporated by parasites at that time 
migrated ahead of the dye front. Fifth, the induced expression of HSPs in oyster hemocytes was accompanied by a relative decrease in synthesis of an actin-like protein of about $45 \mathrm{kDa}$ (Fig. 2 and Tirard et al. 1995), whereas no comparable decrease was observed for the cultured parasites

There are 3 important theoretical and practical implications of these results. First, since HSPs are known to be crucial determinants of cellular stress tolerance in a broad array of single-celled and multicellular animals (Angelidis et al. 1991, Li et al. 1991, Nover 1991. Solomon et al. 1991), the results suggest that Perkinsus marinus may employ HSPs as part of its adaptive survival repertoire. Second, the higher thermal threshold for eliciting the parasite's response suggests that it may bo able to function nomally under sone conditions of hyperthermia that evoke an emergency physiological response from the oyster defense cells. This may afford the parasite an advantage in its interaction with cells of a potential molluscan host. Third, the results indicate that it is feasible to investigate the host's and parasite's adaptive responses to each other in a mixed culture or in vivo, since their individual responses are readily distinguishable.

Because we employed a severe acute hyperthermic shock to demonstrate inducible HSP expression in the parasite and oyster cells, it remains uncertain what relevance the results might have to host-parasite adaptations under environmental conditions that occur more commonly in the natural habitat. Within the range of distribution of Crassostrea virginica, water temperatures occasionally warm to $37^{\circ} \mathrm{C}$ (Galtsof 1964, Paynter \& Dimichele 1990). Furthermore, oysters in the intertidal zones of the U.S. southern coastal regions often are exposed to the sun at low tide, at which time their core temperatures may reach 46 to $49^{\circ} \mathrm{C}$ for up to 2 to 3 h (Galtsof 1964, Kenny et al. 1990). Bodily functions may be maintained if exposure to temperatures as high as $42^{\circ} \mathrm{C}$ is not too prolonged. These are sufficiently severe hyperthermic stresses to activate oyster hemocyte HSP synthesis in vitro or in vivo (Tirard \& Grossfeld unpubl. results) and possibly Perkinsus marinus HSP synthesis as well. Under such extreme conditions, HSPs may contribute to host and parasite adaptations that impact survival of each and the intensity of infection. Might HSPs also be essential for adaptation of these organisms under less severe environmental conditions more characteristically observed in the wild? We suggest that there exists a precedent to expect that they are. The heat shock response of mammalian immune cells is sensitized to heat both by simultaneous exposure to other stressors and by chemical changes occurring in other cell types (Ciavarra \& Simeone 1990). Furthermore, the cellular response to hyperthermia is dependent on the combined influence of intensity and duration of exposure. Thus, a milder heat stress administered over a longer time may have an effect equivalent to a more severe heat stress occurring more transiently if both conditions are sufficient to denature proteins (DiDomenico et al. 1982). These observations suggest that it will be important to exam ine the responses of oyster hemocytes and tissues to acute and chronic thermal stresses in vivo, particularly as they occur during other natural stresses and in field situations.

Acknowledgements. This work has been supported by grants from The University of North Carolina Sea Grant (NA90AAD-SG062, R/MG-9207), The North Carolina Department of Environment Health and Natural Resources, Division of Marine Fisheries (Q3019), and The North Carolina Agricultural Research Foundation (ARS5702)

\section{LITERATURE CITED}

Andrews JD (1988) Epizootiology of the disease caused by the oyster pathogen Perkinsus marinus and its effects on the oyster industry. Am Fish Soc Spec Publ 18:47-63

Angelidis CE, Lazaridis I, Pagoulatos GN (1991) Constitutive expression of heat-shock protein 70 in mammalian cells confers thermoresistance. Eur J Biochem 199:35-39

Calvo LMR, Burreson EM, Paynter KT Jr (1994) Acute osmotic tolerance of cultured cells of the oyster pathogen Perkinsus marinus. J Shellfish Res 13:297

Chu FLE, LaPeyre JF (1993) Perkinsus marinus susceptibility and defense-related activities in eastern oysters Crassostrea virginica: temperature effects. Dis aquat Org 16:223-234

Chu FLE, LaPeyre JF, Burreson C (1993) Perkinsus marinus infection and potential defense-related activities of eastern oysters, Crassostrea virginica: salinity effects. J Invertebr Pathol 62:226-232

Ciavarra RP, Simeone A (1990) T lymphocyte stress response. II. Protection of translation and DNA replication against some forms of stress by prior hyperthermic stress. Cell Immunol 131:11-26

DeNagel DC, Pierce SK (1993) Heat shock proteins in immune responses. Crit Rev Immunol 13:71-81

DiDomenico BJ, Bugaisky GE, Lindquist S (1982) The heat shock response is self-regulated at both the transcriptional and posttranscriptional levels. Cell 31:593-603

Donati YRA, Kantengwa S, Polla BS (1991) Phagocytosis and heat shock response in human monocytes-macrophages. Pathobiol 59:156-161

Fisher WS (1988) Environmental influence on bivalve hemocyte function. Am Fish Soc Spec Publ 18:225-237

Fisher WS, Gauthier JD, Winstead JT (1992) Infection intensity of Perkinsus marinus disease in Crassostrea virginica (Gmelin, 1791) from the Gulf of Mexico maintained under different laboratory conditions. J Shellfish Res 11:363-369

Fisher WS, Tamplin M (1988) Environmental influence on activities and foreign-particle binding by hemocytes of American oysters, Crassostrea virginica. Can J Fish Aquat Sci 45:1309-1315

Ford SE, Haskin HH (1988) Comparison of in vitro salinity tolerance of the oyster parasite, Haplosporidium nelsoni (MSX) and hemocytes from the host, Crasssostrea virginica. Comp Biochem Physiol 90A:183-187

Galtsof PS (1964) The American oyster C virginica (Gmelin). 
US Fish Wild Ser Fish Bull 64:397-446

Gauthier JD, Vasta GR (1993) Continuous in vitro culture of the eastern oyster parasite Perkinsus marinus. J Invertebr Pathol 62:321-323

Haskin HH, Ford SE (1982) Haplosporidium nelsoni (MSX) on Delaware Bay seed oyster beds: a host-parasite relationship along a salinity gradient. J Invertebr Pathol 40: $388-405$

Healy AM, Mariethoz E, Pizurki L, Polla BS (1992) Heat shock proteins in cellular defense mechanisms and immunity. Annls NY Acad Sci 663:319-330

Kantengwa S, Polla BS (1993) Phagocytosis of Staphylococcus aureus induces a selective stress response in human monocytes-macrophages (Mø): modulation by Mø differentiation and by iron. Infect Immun 61:1281-1287

Kenny PD, Michener WK, Allen DM (1990) Spatial and temporal patterns of oyster settlement in a high salinity estuary. J Shellfish Res 9:329-339

Lathigra RB, Butcher PD, Garbe TR, Young DB (1991) Heat shock proteins as virulence factors of pathogens. Curr Top Microbiol Immunol 167:125-143

Li GC, Li LG, Liu YK, Mak JY, Chen LL, Lee WM (1991) Thermal response of rat fibroblasts stably transfected with the human $70-\mathrm{kDa}$ heat shock protein-encoding gene. Proc Natl Acad Sci USA 88:1681-1685

Lindquist S, Craig EA (1988) The heat-shock proteins. A Rev Gen 22:631-677

Morimoto RI (1993) Cells in stress: transcriptional activation of heat shock genes. Science 259:1409-1410

Murray PJ, Young RA (1992) Stress and immunological re-

Responsible Subject Editor: A. K. Sparks, Seattle, Washington, USA cognition in host-pathogen interactions. J Bacteriol 174 4193-4196

Nover L (1991) Heat shock response. CRC Press, Boca Raton

Paynter KT, Dimichele L (1990) Growth of tray-cultured oysters (Crassostrea virginica Gmelin) in Chesa peake Bay. Aquaculture 87:289-297

Polla BS (1991) Heat shock proteins in host-parasite interactions. Immunol Today 12A:38-41

Ragone LM, Burreson EM (1993) Effect of salinity on infection progression and pathogenicity of Perkinsus marinus in the eastern oyster, Crassostrea virginica (Gmelin). J Shellfish Res 12:1-7

Shinnick TM (1991) Heat shock proteins as antigens of bacterial and parasitic pathogens. Curr Top Microbiol Immunol 167:145-160

Solomon JM, Rossi JM, Golic K, McGarry T, Lindquist S (1991) Changes in hsp70 alter thermotolerance and heatshock regulation in Drosophila. New Biol 3:1106-1120

Tirard CT, Grossfeld RM, Levine J, Kennedy-Stoskopf S (1995) Effect of hyperthermia in vitro on stress protein synthesis and accumulation in oyster haemocytes. Fish Shellfish Immunol 5:9-25

Welch WJ, Mizzen LA, Arrigo AP (1989) Structure and function of mammalian stress proteins. In: Pardue ML, Feramisco JR, Lindquist $S$ (eds) UCLA Symposium on Molecular Cell Biology, Vol 96, Stress-induced proteins. Alan R Liss, New York, p 187-202

Young D, Roman E, Moreno C, O'Brien R, Born W (1993) Molecular chaperones and the immune response. Phil Trans R Soc Lond Biol 339:363-367

Manuscript first received: September 21, 1994

Revised version accepted: January 18, 1995 